\title{
Characterization of cerate-zirconate ceramic powder prepared by a high-pressure-high-temperature batch-wise reactor system
}

\author{
Najwa 'Adni Ibarahim • Mohd Azlan Mohd Ishak • \\ Azliana Ramli • Nafisah Osman
}

Received: 12 November 2013/Accepted: 21 June 2014/Published online: 12 July 2014

(C) The Author(s) 2014. This article is published with open access at Springerlink.com

\begin{abstract}
A supercritical technique was proposed to synthesise cerate-zirconate ceramic compound by a highpressure-high-temperature batch-wise reactor system. TG thermogram of the dried powders for all samples showed three stages of weight loss. Each stage is corroborated by one or two exothermic peaks as shown in DTG signal. A complete thermal decomposition for all samples is accomplished at $\sim 977^{\circ} \mathrm{C}$ for $2 \mathrm{~h}$. FT-IR and XRD patterns showed the traces of carbonate residue in the calcined samples is due to the incomplete combustion of intermediate compounds. The presence of secondary phases, namely, $\mathrm{BaZrO}_{3}, \mathrm{BaCeO}_{3}, \mathrm{BaO}_{2}$ and $\mathrm{CeO}_{2}$ as detected by $\mathrm{XRD}$ measurement indicates that the calcined samples are not in a single phase of cerate-zirconate compound.
\end{abstract}

Keywords Ceramic perovskite-type oxides .

Supercritical fluids · Phase formation

\section{Introduction}

Protonic conductors of ceramic perovskite-type oxides $\left(\mathrm{ABO}_{3}\right)$ have captured attention of researchers worldwide for technological purpose in fuel cells, batteries, steam electrolyser, etc. The best candidate amongst them is the

N. 'AdniIbarahim ( $₫)$ · M. A. M. Ishak · A. Ramli · N. Osman Faculty of Applied Sciences, Universiti Teknologi MARA, 02600 Arau, Perlis, Malaysia

e-mail: najwaadni88@yahoo.com

N. Osman

e-mail: fisha@perlis.uitm.edu.my

N. 'Adnilbarahim

Faculty of Applied Sciences, Universiti Teknologi MARA, 40450 Shah Alam, Selangor, Malaysia perovskite-type oxides of $\mathrm{Ba}(\mathrm{Ce}, \mathrm{Zr}) \mathrm{O}_{3}$ which is known to exhibit high mechanical and chemical stability along with good conductivity. This proton conductor is the best applicant as electrolyte for solid oxide fuel cells (SOFC) in the presence of hydrogen and/or water vapour at intermediate temperatures $\left(400-750{ }^{\circ} \mathrm{C}\right)[1,2]$.

Conventionally, the ceramic electrolytes have been prepared by solid-state reaction (SSR) method which employed ball-milled, repetitive grinding and high-temperature treatment $\left(T>1,400{ }^{\circ} \mathrm{C}\right)$. As a consequence, some impurities contaminations were introduced through the heat treatment process which cause sample degradation. To overcome the SSR shortcomings, wet chemical methods (WCMs) such as sol-gel, hydrothermal, co-precipitation, etc. [3-5], are adopted to obtain the desired perovskite compound. WCMs offer fine powder morphologies with less contamination. However, this technique requires longer time and hightemperature treatment $\left(T>1,250{ }^{\circ} \mathrm{C}\right)$ to eliminate organic residues such as carbonate species; thus leads to high energy costs.

Recently, green chemistry technology introduces supercritical fluids (SCF) as one of the promising techniques in synthesising perovskite-type oxide materials. The unique properties of the SCF are the adjustment of its operating conditions as well as physical and chemical parameters (pressure, temperature, and organic solvent) which are difficult to obtain or adjust with conventional processes. The advantages of the SCF are it is a highly versatile technique in producing nano-sized powder and helps to minimise the release of carbon dioxide gas in atmosphere that contributes to massive greenhouse effect and global warming.

The widely used solvents in SCF synthesis as reported in literature are $\mathrm{CO}_{2}, \mathrm{H}_{2} \mathrm{O}, \mathrm{CO}_{2}$ with alcohol, and alcohol [6, 7]. Low carbon alcohols are frequently being used as 
solvent because they can act both as solvent and a reducing agent at supercritical condition [8]. In this present work, a high-pressure-high-temperature (HP-HT) batch-wise reactor system was used to synthesise $\mathrm{BaCe}_{0.54} \mathrm{Zr}_{0.36} \mathrm{Y}_{0.1} \mathrm{O}_{2.95}$ (BCZY) perovskite powder using ethanol as SCF media.

\section{Experimental procedure}

Sample preparation

$\mathrm{Ba}\left(\mathrm{NO}_{3}\right)_{2}(99 \%, \quad \mathrm{ACROS}), \mathrm{Ce}\left(\mathrm{NO}_{3}\right)_{3} \cdot 6 \mathrm{H}_{2} \mathrm{O} \quad(99.5 \%$, ACROS $), \quad \mathrm{Zr}\left(\mathrm{NO}_{3}\right)_{2} \mathrm{O} \cdot x \mathrm{H}_{2} \mathrm{O} \quad(99.5 \%, \quad$ ACROS $)$ and $\mathrm{Y}\left(\mathrm{NO}_{3}\right)_{3} \cdot 5 \mathrm{H}_{2} \mathrm{O}(99.9 \%$, Aldrich) were used as starting or precursor materials. Ethanol (95\%, HmbG) was used as solvent and reaction media. Each metal nitrate salt in stoichiometric amount was dissolved in ethanol. The mixture of the precursor materials was loaded inside a 350-mL vessel and synthesised by a HP-HT batch-wise reactor system. The temperature and pressure of the solvent were controlled at various conditions using a controller as shown in Table 1. The amount of solvent depends on the percentage of liquid level filling or percent of reactor-free volume as reported by Ishak [9]. The facilities involved in monitoring the parameters are flow meters, temperature controller (thermocouple type-K located inside the vessel) and a back-pressure regulator (Unijin). After a fixed period of time, the vessel was transferred into a water bath to quench the reaction immediately. The obtained slurry was subjected to a vacuum suction to separate solid from the slurry. Rotary evaporator was used to evaporate the remaining solvent and the solid product was further calcined at $1,100{ }^{\circ} \mathrm{C}$ at a heating rate of $10{ }^{\circ} \mathrm{C} / \mathrm{min}$.

\section{Sample characterization}

The thermal decomposition process for the as-synthesised dried BCZY powders was analysed by thermogravimetric analyzer/differential scanning calorimeter (TGA/DSC) (TA Instrument, SDT Q600). Approximately 15-18 mg of the dried powder was placed in an alumina crucible pan and gradually heated from 25 to $1,000{ }^{\circ} \mathrm{C}$ with heating rate of $10{ }^{\circ} \mathrm{C} / \mathrm{min}$ under purified air. The infrared spectroscopy

Table 1 Denomination of BCZY sample at different pressures and temperatures

\begin{tabular}{lll}
\hline Denomination & Pressure $(\mathrm{MPa})$ & Temperature $\left({ }^{\circ} \mathrm{C}\right)$ \\
\hline S4 & 4 & 200 \\
S8 & 8 & 200 \\
C6 & 7 & 250 \\
P4 & 4 & 300 \\
P8 & 8 & 300 \\
\hline
\end{tabular}

analysis was performed at room temperature using FT-IR Nicolet 380 spectrophotometer. The IR spectrum was used to observe the formation of metal oxide and detect the remaining carbonate ions of the as-synthesised and calcined powders from 400 to $4,000 \mathrm{~cm}^{-1}$. The phase identification of the samples was carried out by X-ray diffractometer (Shimadzu XRD-6000) equipped with Nifiltered and graphite monochromatized $\mathrm{Cu}-\mathrm{K}_{\alpha}$ radiation ( $\lambda=1.5406 \AA$ ) over a $2 \theta$ range of $10^{\circ}-80^{\circ}$ with step size at $0.02 \%$.

\section{Results and discussion}

Thermogravimetric analysis

The TG-DTG thermograms of the dried powder ( $T=250{ }^{\circ} \mathrm{C}$ ) of BCZY are shown in Fig. 1. All of the samples exhibit almost similar pattern of TG/DTG profiles which consists of three stages of weight loss. Stage 1 takes place in the range of $26-150{ }^{\circ} \mathrm{C}$ with the weight loss of about $\sim 2-4 \%$ corresponding to the evaporation of residual water $\left(\mathrm{H}_{2} \mathrm{O}\right)$ and/or moisture. The second stage at $\sim 150-480{ }^{\circ} \mathrm{C}$ with the weight loss of about $7-14 \%$ is associated with the removal of residual water/moisture, ethanol and decomposition of organic complexes such as nitrate ions. A work done by $\mathrm{Ru}$ et al. [10] also suggested that the volatilization of excess ethanol can be seen at the same range as being observed in this work.

Stage 3 at 400-977 ${ }^{\circ} \mathrm{C}$ shows the largest weight loss of about 16-21\%. It can be devoted to the release of organic residues such as $\mathrm{CO}, \mathrm{CO}_{2}$ and $\mathrm{NO}_{x}$ gasses [11]. At this stage, the decomposition of carbonaceous residues gives rise to the formation of oxide compounds with the release of $\mathrm{CO}_{2}$. There is no apparent change in the weight loss observed when the temperature is higher than $1,000{ }^{\circ} \mathrm{C}$, indicating that the decomposition of $\mathrm{BaCO}_{3}$ and the formation of BCZY may occur. Therefore, it is expected that the minimum temperature of $1,000{ }^{\circ} \mathrm{C}$ is needed to calcine the dried powders.

The possible step-by-step process of weight loss for all samples can be explained as follows:

Step A:

- Boiling point of ethanol $\left(\mathrm{C}_{2} \mathrm{H}_{6} \mathrm{O}\right) \rightarrow 78^{\circ} \mathrm{C}$

- Boiling point of $\mathrm{H}_{2} \mathrm{O} \rightarrow 100{ }^{\circ} \mathrm{C}$

Step B:

- Vapourization of organic complexes obtained from polymerized complex reaction of metal nitrate [10].

- $\mathrm{EtOH} \leftrightarrow$ ethene $+\mathrm{H}_{2} \mathrm{O}$

- Combustion of residual alcohol

- $\mathrm{C}_{2} \mathrm{H}_{5} \mathrm{OH}(\mathrm{liq})+3 \mathrm{O}_{2}(\mathrm{~g}) \rightarrow 2 \mathrm{CO}_{2}(\mathrm{~g})+3 \mathrm{H}_{2} \mathrm{O}(\mathrm{g})$ 

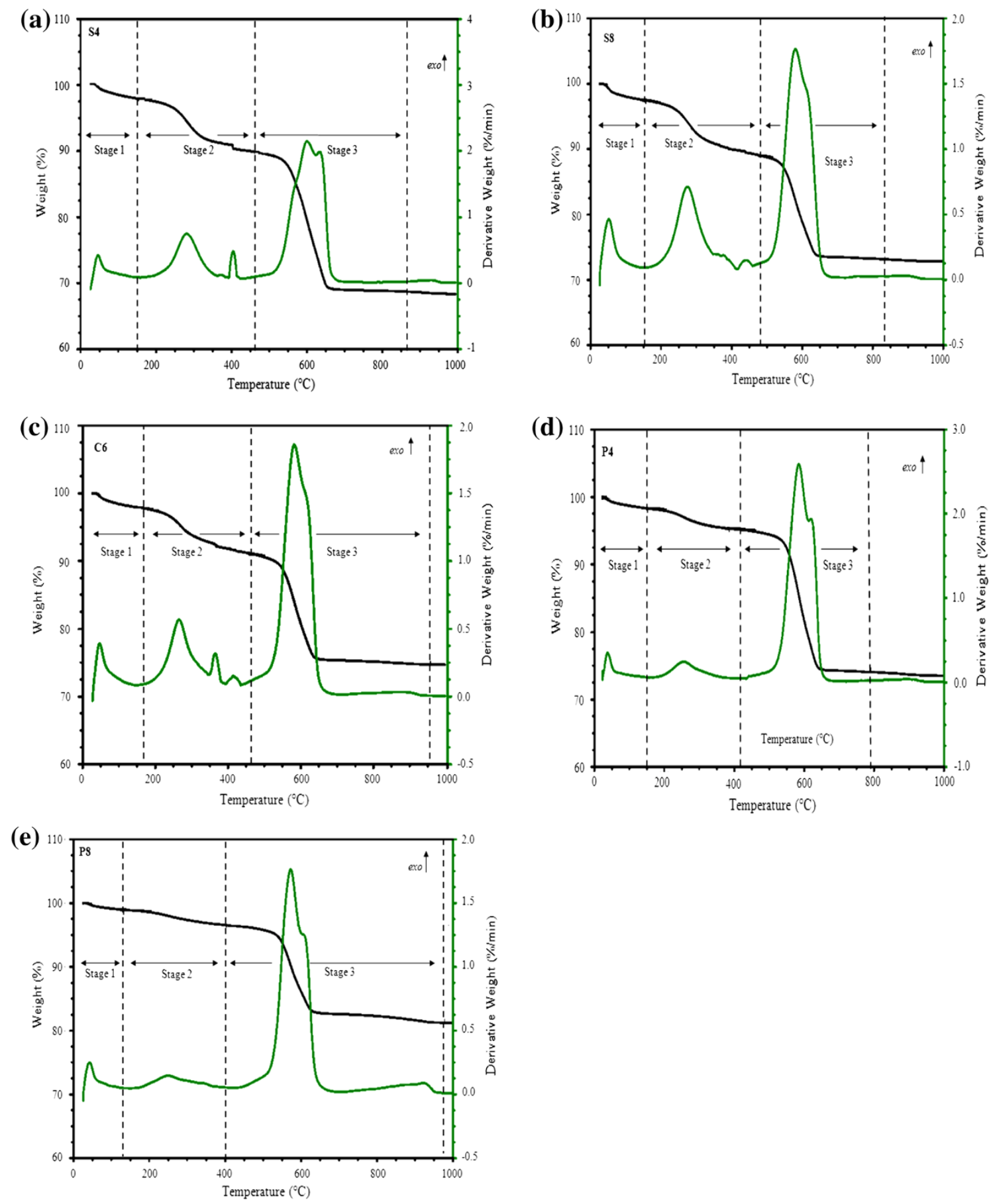

Fig. 1 TG/DTG thermograms of the dried BCZY powders. a S4, b S8, c C6, d P4 and e P8 at different pressures and temperatures

Step C:

- $\mathrm{BaCO}_{3}+\mathrm{Ce}_{1-\mathrm{x}} \mathrm{Zr}_{x} \mathrm{O}_{2} \rightarrow \mathrm{BaCe}_{1-\mathrm{x}} \mathrm{Zr}_{x} \mathrm{O}_{3}+\mathrm{CO}_{2}$

\section{[12].}

A summary of weight loss for all samples is presented in Table 2.
Fourier transform infrared spectroscopy (FT-IR)

The bonding characteristics of functional groups for the as-synthesised and calcined powders were identified by FT-IR spectroscopy as shown in Fig. 2. For the as-synthesised powders, a small absorption band around 
Table 2 Weight loss for dried BCZY powder $\left(T=250{ }^{\circ} \mathrm{C}\right)$

\begin{tabular}{llccl}
\hline Sample & Stage & $\begin{array}{c}\text { Temperature } \\
\text { range }\left({ }^{\circ} \mathrm{C}\right)\end{array}$ & $\begin{array}{l}\text { Weight } \\
\text { loss }(\%)\end{array}$ & $\begin{array}{l}\text { Total weight } \\
\text { loss }(\%)\end{array}$ \\
\hline S4 & 1 & $30-150$ & 2 & 31 \\
& 2 & $150-470$ & 8 & \\
& 3 & $470-860$ & 21 & 28 \\
S8 & 1 & $26-150$ & 3 & \\
& 2 & $150-480$ & 9 & 25 \\
& 3 & $480-830$ & 16 & \\
C6 & 1 & $26-166$ & 2 & \\
& 2 & $166-470$ & 7 & \\
& 3 & $470-950$ & 16 & 26 \\
P4 & 1 & $25-160$ & 2 & \\
& 2 & $160-420$ & 3 & \\
& 3 & $420-830$ & 21 & \\
P8 & 1 & $26-130$ & 2 & \\
& 2 & $130-400$ & 2 & \\
& 3 & $400-977$ & 16 & \\
\hline
\end{tabular}

$1,622 \mathrm{~cm}^{-1}$ for $\mathrm{P} 8$ is characteristic of absorbed water or hydroxyl group (O-H stretching) in ethanol. Broad peak around $1,580-1,552 \mathrm{~cm}^{-1}$ is attributed to bidentate carbonates and/or carboxylate ion. The characteristics of metal precursors bound to nitrate group $\left(\mathrm{M}-\mathrm{NO}_{3}\right)$ for all samples are shown by two absorption peaks that appeared at $\sim 1,421-1,415$ and 1,380-1,358 $\mathrm{cm}^{-1}$, respectively [13]. The presence of a small sharp peak at $816-808 \mathrm{~cm}^{-1}$ indicates that the samples consist of carbonate species as secondary phases due to decomposition of metal nitrate with $\mathrm{CO}_{2}$. The formation of metal-oxygen $(\mathrm{M}-\mathrm{O})$ bond in the prepared sample is represented by small sharp peak at $729-720 \mathrm{~cm}^{-1}$ for S4, S8 and C6 which is in-line with the work done by Li et al. [14]. The presence of metal oxides is noticeable for S4, S8, and P8 by the appearance of broad adsorption bands at $542-466 \mathrm{~cm}^{-1}$.
Fig. 2 FT-IR spectra of BCZY powders. a As-synthesised. b After calcined at $T=1,100{ }^{\circ} \mathrm{C}$
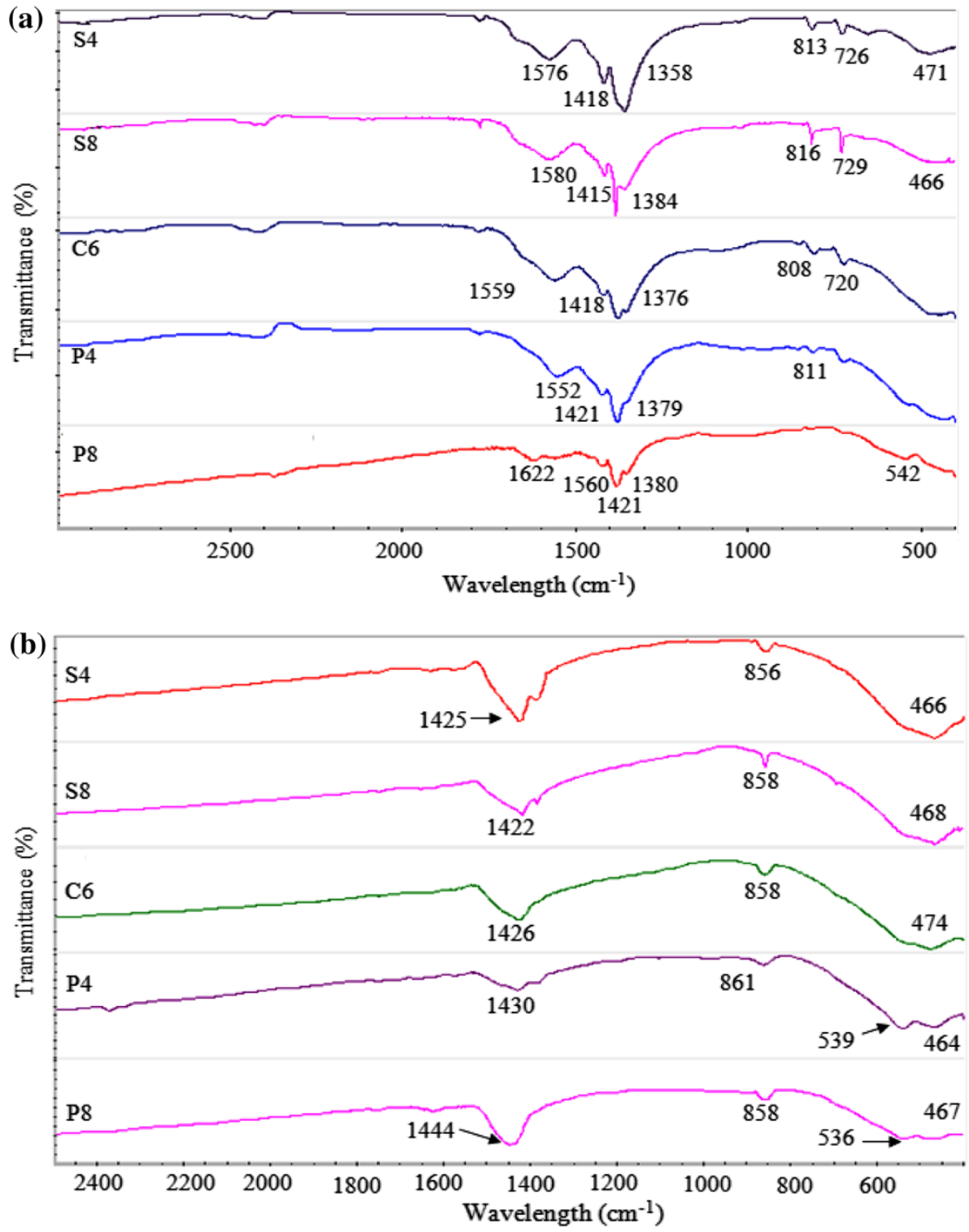
In Fig. 2b, as calcination temperature is increased to $1,100{ }^{\circ} \mathrm{C}$, the bands associated to the $-\mathrm{OH}$ and other organic compounds vibration became weaker and the bands for the metal-oxygen vibration became stronger. However, the presence of impurities such as nitrate species at $\sim 1,444-1,422 \mathrm{~cm}^{-1}$ [15] and carbonate residue at $861-856 \mathrm{~cm}^{-1}$ are still being detected in the spectra. Carbonate compound was formed due to the incomplete combustion of excessive organic matter with $\mathrm{Ba}(\mathrm{NO})_{2}$ [13]. According to Robertz et al. and Osman et al., high calcination temperatures ranging from 1,400 to $1,500{ }^{\circ} \mathrm{C}$ are needed to decompose the carbonate traces and undesired secondary phases $[12,16]$. The broad absorption bands between 539 and $464 \mathrm{~cm}^{-1}$ indicate the presence of metal oxides in the samples.

\section{$\mathrm{X}$-ray diffraction $(\mathrm{XRD})$}

Figure 3 shows XRD patterns of the prepared powders after they were calcined at $1,100{ }^{\circ} \mathrm{C}$. All samples exhibit a mixture of respective $\mathrm{BaZrO}_{3}, \mathrm{BaCeO}_{3}, \mathrm{CeO}_{2}, \mathrm{BaO}_{2}$ and $\mathrm{BaCO}_{3}$. For example, peak at $2 \theta=28.5^{\circ}$ is corresponded to the $\mathrm{BaCeO}_{3}$ (JCPDS card- 220,074) and at $2 \theta=30^{\circ}$ for $\mathrm{BaZrO}_{3}$ (JCPDS card- 60039). The SCF condition used in this work also produces $\mathrm{CeO}_{2}$ and $\mathrm{BaO}_{2}$, which are initial compounds to form $\mathrm{BaCeO}_{3}$. Detailed literature survey showed that single metal oxides or/and perovskite phase can be obtained if the sample has only 2-3 metal elements such as $\mathrm{BaTiO}_{3}, \mathrm{TiO}_{2}$, and $\mathrm{ZrO}_{2}[8,17,18]$. For the sample consisting of four metal elements, the conditions used in SCF are not suitable and sufficient enough to produce a single perovskite of $\mathrm{Ba}(\mathrm{Ce}, \mathrm{Zr}) \mathrm{O}_{3}$. On the other hand, the formation of $\mathrm{BaCO}_{3}$ is due to the reaction between $\mathrm{Ba}^{2+}$ and $\mathrm{CO}_{3}{ }^{2-}$ during the calcination process. Therefore,

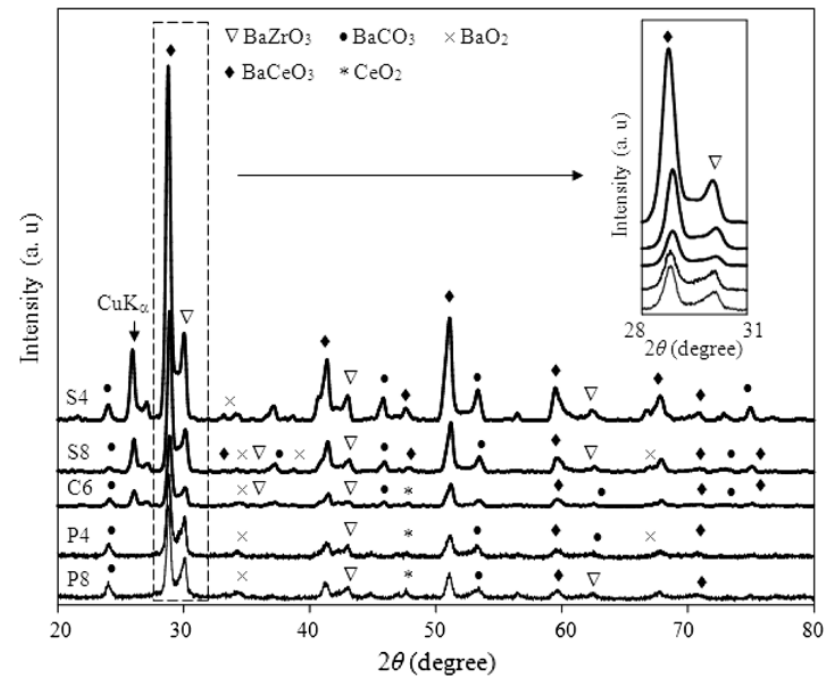

Fig. 3 XRD patterns for prepared powder after calcined at $1,100{ }^{\circ} \mathrm{C}$ further modification technique using a supercritical fluid that assisted with sol-gel method to produce a single BCZY phase will be applied in our future work.

\section{Conclusion}

A precursor of metal nitrate salts in stoichiometric amount was synthesised by a supercritical ethanol at different pressures and temperatures. The dried powder was decomposed at $\sim 977{ }^{\circ} \mathrm{C}$ based on TG-DTG results. The analyses of FT-IR and XRD data clearly revealed that the prepared sample consists of carbonate species and secondary phase mainly individual perovskite of $\mathrm{BaCeO}_{3}$, $\mathrm{BaZrO}_{3}$, and metal oxides, respectively. The parameters of $\mathrm{ScEtOH}$, particularly pressure and solubility were not desirable enough to bind the metal elements and hindered the formation of carbonate species at an early state. Consequently, the incomplete reaction produces $\mathrm{BaCO}_{3}$ and other secondary phases. Therefore, we conclude that the conditions used in SCF in this work were not sufficient to substitute Ce into $\mathrm{Zr}$ site to form a single phase of ceratezirconate compound. Modification on the synthesis route is still in progress and will be reported elsewhere.

Acknowledgments The authors would like to thank the Ministry of Education (MOE), Malaysia for the Research Articulation Grant Scheme (RAGS), Exploratory Research Grant Scheme (ERGS) and Universiti Teknologi MARA for the internal grant and facilities support.

Open Access This article is distributed under the terms of the Creative Commons Attribution License which permits any use, distribution, and reproduction in any medium, provided the original author(s) and the source are credited.

\section{References}

1. Katahira K, Kohchi Y, Shimura T, Iwahara H (2000) Protonic conduction in $\mathrm{Zr}$-substituted $\mathrm{BaCeO}_{3}$. Solid State Ion 138:91-98

2. Babilo P, Haile SM (2005) Enhanced sintering of yttrium-doped Barium Zirconate by addition of ZnO. J Am Ceram Soc 88:2362-2368

3. Osman N, Talib IA, Hamid HA (2008) Properties of sol-gel prepared $\mathrm{BaCeO}_{3}$ solid electrolyte using acetate precursors. Ionics 15:203-208

4. Amini MM, Mirzaee M (2009) Effect of solvent and temperature on the preparation of potassium niobate by hydrothermal-assisted sol-gel processing. Ceram Int 35:2367-2372

5. Boschini F, Rulmont A, Cloots R, Vertruyen B (2009) Rapid synthesis of submicron crystalline barium zirconate $\mathrm{BaZrO}_{3}$ by precipitation in aqueous basic solution below $100{ }^{\circ} \mathrm{C}$. J Eur Ceram Soc 29:1457-1462

6. Aymonier C, Serani LA, Reveron H, Garrabos Y, Cansell F (2006) Review of supercritical fluids in organic material science. J Supercrit Fluids 38:242-251

7. Aimable A, Xin B, Millot N, Aymes D (2008) Continuous hydrothermal synthesis of nanometric $\mathrm{BaZrO}_{3}$ in supercritical water. J Solid State Chem 181:183-189 
8. Kim J, Kim D, Veriansyah B, Kang JW, Kim J-D (2009) Metal nanoparticle synthesis using supercritical alcohol. Mater Lett 63:1880-1882

9. Ishak MAM (2007) A Study on liquefaction of pretreated mukah balingan low rank malaysia coal, Chapter 3: Materials and methods, 25

10. Ru Y, Jie Q, Min L, Guoqiang L (2008) Synthesis of yttrium aluminum garnet (YAG) powder by homogeneous precipitation combined with supercritical carbon dioxide or ethanol fluid drying. J Eur Ceram Soc 28:2903-2914

11. Singh KA, Pathak LC, Roy SK (2007) Effect of citric acid on the synthesis of nano-crystalline yttria stabilized zirconia powders by nitrate-citrate process. Ceram Int 33:1463-1468

12. Osman N, Talib IA, Hamid HA (2010) Preparation and characterization of $\mathrm{Yb}$-doped $\mathrm{Ba}(\mathrm{Ce}, \mathrm{Zr}) \mathrm{O}_{3}$ nanopowders with high sinterability. Ionics 16:561-569

13. Nityanand C, Nalin WB, Rajkumar BS, Chandra CM (2011) Synthesis and physicochemical characterization of nanocrystalline cobalt doped lanthanum strontium ferrite. Solid State Sci 13:1022-1030

14. Li Y, Zhao J, Wang B (2004) Low temperature preparation of nanocrystalline $\mathrm{Sr}_{0.5} \mathrm{Ba}_{0.5} \mathrm{Nb}_{2} \mathrm{O}_{6}$ powders using an aqueous organic gel route. Mater Res Bull 39:365-374

15. Milt VG, Ulla MA, Miro EE (2005) $\mathrm{NO}_{\mathrm{x}}$ trapping and soot combustion on $\mathrm{BaCoO}_{3-\mathrm{y}}$ perovskite: LRS and FTIR characterization. Appl Catal B 57:13-21

16. Robertz B, Boschini F, Rulmont A, Clossts R (2003) Preparation of $\mathrm{BaZrO}_{3}$ powders by a spray-drying process. J Mater Res 18:1325-1332

17. Alonso E, Montequi I, Lucas S, Cocero MJ (2007) Synthesis of titanium oxide particles in supercritical $\mathrm{CO}_{2}$ : effect of operational variables in the characteristics of the final product. J Supercrit Fluids 39:453-461

18. Byrappa K, Ohara S, Adschiri T (2008) Nanoparticles synthesis using supercritical fluid technology-towards biomedical applications. Adv Drug Deliv Rev 60:299-327 